Published in final edited form as:

Vascular. 2009 ; 17(Suppl 1): S30-S39.

\title{
Gender Differences in Abdominal Aortic Aneurysms
}

\author{
Kevin K. Hannawa, Jonathan L. Eliason, and Gilbert R. Upchurch Jr. \\ Jobst Vascular Research Laboratories, Section of Vascular Surgery, Department of Surgery, \\ University of Michigan, Ann Arbor MI
}

\section{Abstract}

Abdominal aortic aneurysms (AAAs) comprise the 10th leading cause of death in Caucasian males 65-74 years of age, and accounted for nearly 16,000 deaths overall in the year 2000. Therefore, understanding the pathophysiology of AAAs is an important undertaking. Clinically, multiple risk factors are associated with the development of AAAs, including increasing age, positive smoking history, and hypertension. Male gender is also a well-established risk factor for the development of an AAA with a 4:1 male to female ratio. The reason for this gender disparity is unknown. The pathogenesis of AAAs formation is complex and multifactorial. Histologically, AAAs are characterized by early chemokine driven leukocyte infiltration into the aortic wall. Subsequent destruction of elastin and collagen in the media and adventitia ensues due to excessive local production of matrix degrading enzymes, and is accompanied by smooth muscle cell loss and thinning of the aortic wall. At present, there are no medical therapies available to treat patients with aortic aneurysms, using only the crude measurement of aortic diameter as a threshold for which patients must undergo life-threatening and costly surgery. Defining the early mechanisms underlying gender-related differences in AAA formation are critical, as understanding differences in disease patterns based on gender may allow us to develop new translational approaches to the prevention and treatment of patients with aortic aneurysms.

\section{Introduction}

Abdominal aortic aneurysms (AAAs), defined as an aortic diameter (AD) $>3.0 \mathrm{~cm},{ }^{1}$ are a common clinical condition in adult patients and can lead to serious life-threatening complications if not addressed. According to the National Center for Health Statistics, AAAs are the cause of over 12,000 deaths annually and ranks as the $15^{\text {th }}$ leading cause of death among all individuals aged $55-85 .^{2}$ Recent advances in screening and therapy, such as endovascular aneurysm repair, have led to improved detection and lower mortality rates. ${ }^{3-8}$

The pathogenesis of AAAs involves a complex series of events that have not been fully elucidated yet, as most studies of AAAs primarily involve cohort studies from the end-stage of the disease process. Characteristics of aneurysm development include: degradation of elastin and collagen in the media and adventitia, release of cytokines and chemokines, and an oxidative burst resulting from a catalytic process that occurs following infiltration of inflammatory cells into the aortic wall. ${ }^{9-13}$

Corresponding author: Gilbert R. Upchurch, Jr., M.D., FACS, 1500 E. Medical Center Drive, CVC, Ann Arbor, MI 48109-0329, Telephone: (743) 936-5790, Fax: (734) 647-9867, riversu@umich.edu.

Prepared by invitation for a basic science edition of Vascular 


\section{Clinical Impact of Gender on AAA}

Clinical risk factors for AAA including advanced age, family history, smoking history, atherosclerosis, hypertension, and chronic obstructive pulmonary disease (COPD), are equally distributed between males and females. ${ }^{5}, 14,15$ In contrast, females seem to be protected from developing AAAs. Lederle et al. documented that female gender was considered a negative risk factor for developing a small AAA [OR 0.47 (CI 0.32-0.69) for $\mathrm{AD} 3.0-3.9 \mathrm{~cm}$, OR 0.18 (CI 0.07-0.48) for $\mathrm{AD}>4.0 \mathrm{~cm}]{ }^{5}$ In contrast, the prevalence of AAAs amongst males greater than 50 years old is $4-5$ times greater than females of the same age. ${ }^{15,16}$ As one ages, the prevalence of AAAs increases with males, reaching a peak prevalence of 5.9\% at 80-85 years of age and then decreasing afterwards. In women the prevalence increases to $4.5 \%$ after age 90 years of age. ${ }^{17}$ After analyzing population based screening studies, Bengtsson et al. demonstrated that AAAs develop 10-15 years later in women. ${ }^{17}$ Speculation as to why this occurs may be due to decreased circulating levels of estrogen in post-menopausal women, as has been suggested by investigational studies in rodents. ${ }^{18}$

Observations such as these have diminished the enthusiasm for screening women for AAAs, even those with a significant number of risk factors for developing an AAA. Currently, the United States Preventive Task Force provides a grade D recommendation for screening for AAA among women due to the low prevalence of the disease. ${ }^{19}$ However, this recommendation conflicts with the Society of Vascular Surgery and the Society for Vascular Medicine and Biology who recommend screening for women aged 60-85 with cardiovascular risk factors or greater 50 years old with a family history of AAA. ${ }^{20}$ Derubertis et al. recently documented that women of advanced age ( $\geq 65$ years) with a history of smoking or heart disease should be considered for AAA screening. ${ }^{21}$

Regarding different thresholds for AAA repair among gender, the 2005 ACC/AHA practice guidelines recommends an AAA diameter of $5.5 \mathrm{~cm}$ as a lower limit with no mention of variation between sexes. ${ }^{1}$ However, numerous studies have documented that females consistently suffer significantly higher mortality rates compared to males following elective AAA (eAAA) repair (Figure 1), ruptured AAA (rAAA) repair, and endovascular AAA repair (EVAR). ${ }^{4}, 16,22-24$ Methods suggested to decrease mortality rates in females include referral to high volume hospitals ${ }^{23}$ or decreasing the diameter threshold for repair. ${ }^{3,} 25$ According to Dimick et al., there were significant decreases in mortality rates for women undergoing AAA repair when they were admitted to a high-volume hospital, verus a lowvolume hospital. (Table 1). ${ }^{23}$ In addition, numerous retrospective studies have suggested an almost paternalistic approach by caregivers for women with AAAs, as females were less likely than males to undergo eAAA repair, rAAA, or EVAR. ${ }^{4}, 16,22$ Anatomical contraindications, such as small iliac arteries or a small aortic bifurcation diameter, and increased intraoperative morbidity, such as iliac artery occlusions, dissections, and ruptures, are factors which occur more frequently in females, and may preclude women from undergoing EVAR, with its attendant lower short term mortality. ${ }^{26}$

A lower threshold for eAAA repair in women at $\mathrm{AD}$ of $4.5 \mathrm{~cm}$ to $5.0 \mathrm{~cm}$, which is in contradiction to the 2005 ACC/AHA practice guidelines, has been recommended by the American Association for Vascular Surgery and Society of Vascular Surgery. ${ }^{3}$ Evidence to support this recommendation was primarily based on a study by Brown et al. which reviewed risks of small aneurysm rupture in patients undergoing ultrasound surveillance. The study documented that female sex was significantly associated with aneurysm rupture (HR 4.50, CI 1.98-10.2, $\mathrm{p}=0.001$ ) and that mean AD at rupture was $5 \mathrm{~cm}$ in women versus $6 \mathrm{~cm}$ in men. ${ }^{25}$ Reasons for these differences may be that aneurysms of the same size in both sexes represent more advanced disease in the females, who generally have smaller initial 
aortic diameters. ${ }^{27,}{ }^{28}$ An alternative hypothesis is that, while AAAs occur less frequently in females, women have faster growth rates of their aorta compared to males secondary to increased inflammation in the aortic wall once they have a small AAA. ${ }^{29}, 30$

There are other disease states associated with an increased incidence of aortic aneurysms, such as polycystic kidney disease (PKD), in which the severity of the disease is associated with alterations in gonadal hormones. A recent study by Smith suggested that testosterone is associated with a decline in renal function, while estrogen was protective in mice with juvenile cystic disease. ${ }^{31} \mathrm{~A}$ link between steroid hormones and MMP9 and MMP1 in patients with PKD has been established. ${ }^{32}$ A link between Turner syndrome, a chromosomal deletion leaving patients with an XO sex linked chromosome pair, and aortic disease is also well documented. ${ }^{33}$ Observations such as these have led some to suggest that: "Males and females have different patterns of illness .... Understanding the basis of these gender-based differences is important to developing new approaches to prevention, diagnosis, and treatment." 34

\section{Increasing Incidence of AAAs in Males in Rodent Experimental Models}

The mechanism(s) by which aneurysms are initiated and the series of events by which an AAA forms are poorly understood. ${ }^{35}$ While the specific etiology is unclear, AAAs are initiated by some unknown aortic wall injury. In a conducive genetic and environmental background, recruitment of leukocytes into the aortic wall media and adventitia by chemokines appears to be an early and critical event. These chemokines may be secreted by a number of cells, including leukocytes and smooth muscle cells. Subsequent leukocyte infiltration into the aortic wall is associated with the production of many pro-inflammatory cytokines as part of the innate inflammatory response. It is during this stage that a number of matrix degrading enzymes are released, leading to aortic wall elastin and collagen degradation. With continued aortic wall thinning secondary to SMC apoptosis ${ }^{36}$ and elastin fragmentation, AAA formation occurs.

Three published reports have directly compared male and female animals in experimental AAA models and have suggested that, similar to humans, females are protected from AAA formation. ${ }^{18,}$, 37, 38 Daugherty documented in ATII-induced AAAs in apolipoprotein E -/and LDL receptor $-/-$ mice, males are more susceptible to aneurysm development than females. ${ }^{39}$ Interestingly, in the initial report using this model ${ }^{38}$ describing suprarenal aortic aneurysm formation, female mice were used exclusively and only $20 \%$ and $33 \%$ of mice developed an AAA. In subsequent studies, male mice have been used primarily and develop an AAA approximately $80 \%$ of the time. ${ }^{38}$

In the elastase-induced rodent aortic aneurysm model, a report from our laboratory documented that males form AAAs more often than females, and that this was associated with an increase in the number of MMP9 secreting macrophages in the aortic wall. ${ }^{18}$ The mean increase in aortic diameter 14 days after elastase perfusion in male (M) aortas was 200 $\pm 38 \%$, while female $(\mathrm{F})$ aortas had an increase of only $69 \pm 27 \%(\mathrm{P}=.023)$. The incidence of AAAs, defined as a $100 \%$ increase in aortic diameter from baseline, was $82 \%$ in males compared to $29 \%$ in female rats $(\mathrm{P}=.023)$. A follow-up study in the rat elastase model in males using microarrays also suggested that early (day 3) during AAA development the androgen receptor and the estrogen-related $\alpha$ receptor are down regulated 50 fold and 126 fold, respectively, compared to control animals. ${ }^{40}$ A number of other cytokines, including IL-1, were also found to be down-regulated in females compared with males. ${ }^{41}$ (Table 2)

Recent experiments in our laboratory have confirmed that the phenotypic changes that occur in rats also occur in mice in the elastase-induded AAA model. In these experiments, male and female mice underwent isolated elastase or heat-inactived elastase aortic perfusion. The 
results were similar to rats, in that male mice form larger AAAs with increased incidence compared with female mice. (Figure 2A) In addition, MMP9 and MMP2 activity as determined by zymography is increased in the mouse aortic wall in males compared with females. (Figure 2B)

\section{Recruitment of Leukocytes is Critical during Early AAA Formation}

The pathogenesis of AAAs involves a complex series of events, characterized ultimately by the degradation of elastin and collagen in the media and adventitia through a catalytic process that occurs following infiltration of inflammatory cells into the aortic wall. ${ }^{10,}, 12,42-$ 45 The macrophage, in particular, has been implicated as critical in the pathogenesis of AAAs. ${ }^{46}$ The importance of the neutrophil during AAA formation, while not as well studied, has also been established in humans ${ }^{47-49}$ and, recently, in a mouse model of aneurysm formation. ${ }^{50}$

The broad context for another study from our laboratory using a neutrophil depletion strategy prior to AAA formation was to better define the role of the neutrophil in the sequence of events leading to AAA formation. ${ }^{50}$ Briefly, control, rabbit serum treated, (RS, $\mathrm{n}=27$ ) or anti-neutrophil antibody treated (Anti-PMN, $n=25)$ C57BL/6 mice underwent aortic elastase perfusion to induce experimental aneurysms. Control mice 14 days after elastase perfusion exhibited a mean aortic diameter (AD) increase of $104 \% \pm 14 \%(\mathrm{P}<$ 0.001 ), and $67 \%$ developed AAAs, while Anti-PMN-treated mice exhibited a mean AD increase of only $42 \% \pm 33 \%$ with $8 \%$ developing AAAs. Tissue neutrophils and macrophages 14 days after elastase perfusion were significantly decreased in the Anti-PMN group compared to controls. Earlier time-points (4 and 7 days) reflected these differences as well.

The mechanism by which neutrophils and macrophages are recruited into the aortic wall during aneurysm formation are critical early events during AAA formation, ${ }^{51}$ and appear to be mediated by two primary mechanisms: 1) soluble mediators, including chemokines and cytokines, and 2) cell specific receptors such as the selectins. Mutliple chemokines and cytokines have been studied in both human and experimental AAAs. The CC chemokines appear to be critical during AAA formation and have previously been shown to be important intermediaries during the initial inflammatory process leading to AAA formation. ${ }^{52}$, 53 Each of these chemokines, while not completely selective, tends to recruit a particular cell type to sites of inflammation. For example, MIP2 and KC (human IL8) are primarily associated with recruitment of neutrophils, while MIP1 $\alpha$ and MCP-1 (CCL2) are involved in the recruitment of macrophages. ${ }^{52,53}$ MIP- $1 \alpha$ has been shown to be up-regulated in macrophages in response to in hyperlipidemic apo $\mathrm{E}^{-/-}$and $\mathrm{Ldlr}^{-/-}$mice that form AAAs. ${ }^{54}$ MCP1 is leukotriene $\mathrm{LTD}_{4}$ essential for monocyte recruitment in vivo in several different inflammatory models, ${ }^{55-57}$ and is up-regulated in both mouse and human AAAs. ${ }^{58,}$, 59 The importance of MCP1, in particular, during AAA formation is also supported by the observation that mice deficient in CCR2 receptor fail to develop aneurysms in the ATIIinduced apo E -/- mice. ${ }^{60}$ This observation is associated with a marked decrease in monocyte-mediated inflammation in the aortic wall and an increase in IL1 $\beta$ expression.

In separate experiments in mice using the elastase perfusion AAA model, the temporal course of MCP1 expression and protein levels was defined. ${ }^{58}$ Mouse aortic diameter (mean + - - SEM) increased to aneurysmal proportions 14 days after elastase perfusion (from $0.51+$ / $-0.03 \mathrm{~mm}$ to $1.34+/-0.32 \mathrm{~mm}$; $163 \%$ increase; $\mathrm{P}<.05$ ). Aortic wall messenger RNA expression increased 28- fold for MCP1 on day 4, with maximal production of chemokine protein on day 7. These data suggest that increased aortic wall expression of MCP1 occurs early in development of elastase-induced AAAs before the onset of the chronic 
inflammatory response. The source of MCP1 was aortic SMCs, providing an important link between enzymatic injury, leukocyte recruitment, and aneurysmal degeneration of the aortic wall.

Another group of soluble mediators involved early in the cascade of events that occurs during AAA formation are cytokines, which serve as cytotoxic mediators damaging SMCs in the aortic wall. Two well-studied cytokines, TNF $\alpha$ and IL1 $\beta$ may play a central role in the gender disparity seen during AAA formation. Importantly, increased serum and tissue levels of TNF $\alpha$ and IL1 $\beta$ have been documented in patients with aortic aneurysmys. ${ }^{61,62}$ These two cytokines are particularly relevant during AAA formation as they both inhibit Type I and III collagen synthesis. ${ }^{63,}{ }^{64}$ In general, while often cited as having similar effects in inflammatory and septic models, a recent study has demonstrated enhanced TNF $\alpha$ expression without corresponding changes in IL1 $\beta$ in small AAAs. ${ }^{65}$ Temporal and concentration differences in the expression of these two cytokines may be critical during the observed differential phenotypic expression of AAA between males and females. The expression of MMPs and TIMPs are also controlled in part at the transcriptional level by cytokines.

In addition to the multiple potential soluble mediators of early leukocyte recruitment during AAA formation, various cell-based receptors are also critical during this process. One group of adhesion molecules that may be relevant is the selectins. The selectins are a family of three adhesion molecules: 1) E-selectin on the surface of activated endothelial cells, 2) Pselectin on the surface of activated platelets and endothelial cells, and 3) L-selectin constitutively expressed on the surface of most leukocytes (PMNs and macrophages). ${ }^{66,67}$ The primary function of selectins is to promote leukocyte capture to sites of inflammation. Without selectins, inflammatory cell recruitment is significantly diminished. ${ }^{6-72}$

The critical role of L-selectin in AAA formation in male rodents has been studied extensively in our laboratory. ${ }^{73}$ Briefly, male rat abdominal aortas were perfused with saline or elastase and studied on post-perfusion days 1, 2, 4, 7, and 14. L-selectin expression and protein levels in aortic tissue were determined by PCR and western blot, respectively. Elastase perfused aortic diameters were significantly increased compared to control aortas at all time points except day $1(\mathrm{P}<.05)$. L-selectin mRNA expression in elastase perfused aortas were $18(\mathrm{P}=.018), 17(\mathrm{P}<.001)$ and 8 times $(\mathrm{P}=.02)$ times greater than control aortas at days 1,2, and 4, respectively. Western blot demonstrated a significant $69 \%$ increase in L-selectin protein at day 7 in elastase compared to saline perfused aortas $(\mathrm{P}=$. 005). Subsequent experiments involved studies on post-elastase perfusion days 4, 7, and 14 of aortas from C57Bl Wt $(\mathrm{N}=21)$ and L-selectin knockout $(\mathrm{LKO})$ mice $(\mathrm{N}=19)$. LKO mice had significantly smaller aortic diameters at day 14 compared to Wt mice. PMN counts were significantly greater in elastase perfused $\mathrm{Wt}$ mouse aortas compared to LKO mouse aortas at day 4 post-perfusion ( 12.8 vs. $4.8 \mathrm{PMNs} / \mathrm{HPF}, \mathrm{P}=.02$ ). Macrophage counts were significantly greater at all time points in elastase perfused WT mouse aortas compared to elastase perfused LKO mouse aortas, with a maximum difference at day 7 post-perfusion (13.3 vs. 0.5 macrophages/HPF, $\mathrm{P}<.001$ )

In separate experiments from our laboratory to document phenotypic and mechanistic changes in AAA formation, male $\mathrm{Wt}(\mathrm{n}=17)$ and P-selectin knock-out $(\mathrm{n}=10)-/-$ mice (PKO) underwent elastase perfusion, and aortic diameters were determined post-perfusion day $14 .{ }^{74}$ The results document that, even to a greater extent than L-selectin $-/-$ mice, the absence of P-selectin inhibits AAA formation $(\mathrm{P}<0.001)$. (Figure 3) 


\section{Manipulation of Gonadal Hormones Alters Leukocyte Trafficking and Aortic Wall Degradation}

While few studies have examined the role of pharmacologic or surgical alteration of gonadal hormones on leukocyte recruitment during AAA formation, a protective role for estrogen and its derivatives in AAA formation receives indirect support from a number of studies. A study in the AT-II induced AAA model suggested that 17ß-estradiol implanted subcutaneously attenuates aneurysm development. ${ }^{75}$ Inhibition of proinflammatory genes, including MCP1, was proposed as the mechanism responsible for this effect. It has been suggested that orchidectomy, not ovariectomy, is capable of altering gender-specific rates of AAA formation. ${ }^{76}$

Our laboratory confirmed the inhibitory effects of estradiol in the aortic elastase-perfusion rodent model. ${ }^{18}$ Male rats were randomized to implantation of an estrogen pellet or sham implantation ( $\mathrm{n}=13$, each). Rat aortas from both groups were subjected to elastase perfusion 5 days later. The aortic size was then determined 14 days following elastase perfusion and the aorta was excised for study. By day 14, male rats receiving estradiol (ME) had significantly smaller aneurysms $(241 \% \pm 57)$ compared to sham rats (MS, 538\% $\pm 105, \mathrm{P}=$. $023) .{ }^{18} \mathrm{ED}-1$ positive cell counts (mononuclear leukocyte lineage) were $1.8 \pm 0.3$ cells/HPF in males receiving estradiol (ME) versus $5.2 \pm 0.5$ cells/HPF male sham (MS) rats ( $* \mathrm{P}=$. 0006).

Multiple observations from the trauma and sepsis literature suggest that gonadal hormones regulate leukocyte trafficking. Chaudry and others developed the hypothesis that leukocyte immune responses, through multiple soluble mediators, are depressed in males and enhanced in females following trauma and hemorrhage. ${ }^{77-82}$ Other models have also been used to examine the role of estrogen on leukocyte migration. In rat carotid arteries following acute balloon injury, a large number of leukocytes (neutrophils and macrophages) invade the carotid artery within 24 hours following injury. This response is markedly blunted by exogenous estrogen. Following ovariectomy in rats, estrogen therapy is able to negatively modulate the pro-inflammatory response by altering expression and protein levels of a number of chemokines and cytokines, including MCP1, IL1 $\beta$, and TNF $\alpha$. Inhibition of these chemokines and cytokines by estrogen in oopherectomized animals translated into decreased migration of neutrophils in a chemotaxis assay. ${ }^{83-85}$ Estrogen also has a direct inhibitory effect on macrophage recruitment, through its effects on MCP1 ${ }^{86-89}$ Furthermore, increased estrogen levels in women, including those on estrogen replacement therapy, correlated with reductions in circulating MCP1 levels.

Gonadal hormones may also affect AAA formation through their effects on gonadal receptors. Mutliple genetic studies have suggested a role for the estrogen receptors in influencing cardiovascular disease. While not examined in detail experimentally in the development of AAAs, vascular SMCs express functional estrogen receptor (ER) $\alpha$ and $\beta$. ER $\alpha$ polymorphisms are associated with premature coronary artery disease in men ${ }^{90}$ and postmenopausal women. ${ }^{91}$ Similarly, a polymorphism in the ER $\beta$ gene has been documented in post-menopausal Japanese women with hypertension, ${ }^{92}$ a known risk factor for aneurysm development.

Estrogen may also affect AAA development by directly inhibiting macrophage and SMC production of MMPs. For example, estrogen treatment of U937 cells decreases MMP-2 production directly. ${ }^{93}$ In a study by Potier and others, estrogen and progesterone differentially regulated MMP-9 and MMP-2 expression and activity in aortic arch-derived smooth muscle cells isolated from atherosclerosis-susceptible and -resistant mice. ${ }^{94}$ Animals 
treated with estradiol also have decreased vascular smooth muscle cell contractility and proliferation. ${ }^{95}$

A third possible mechanism by which gender might alter AAA formation is through the effect of gonadal hormones on aortic wall ECM proteins. In particular, the influence of sex hormones on aortic wall elastin and collagen degradation has been studied. Fischer and Swain examined the effects of castration in the presence of testosterone and estradiol in male rats and concluded that: 1) estradiol, in the presence or absence of testosterone, alters the proportions of collagen and elastin so that the vessel is more distensible, and 2) testosterone has the opposite, but markedly less, effect of estradiol on vascular tissue. ${ }^{96}$ These studies were extended by Simpson and Cardeilhac who, following the administration of beta-aminopropionitrile (BAPN) in turkeys, demonstrated that $65 \%$ of BAPN-treated male turkeys died of dissecting aneurysms, while only $21 \%$ of females died of the same disease. Ultrastructural alterations in aortic collagen and elastin occurred more frequently in males. ${ }^{97}$ Potier and others also suggested that estrogen differentially regulates collagen in atherosclerosis-susceptible and atherosclerosis-resistant mice. ${ }^{94}$ In postmenopausal women, phytoestrogens result in decreased aortic stiffness. ${ }^{98}$

\section{Summary}

Despite human epidemiologic and animal investigational data strongly supporting a gender bias in the development of AAAs, little is known about the specific mechanisms driving this disparity. This review provides data supporting the concept that gonadal hormones and their receptors work through multiple mechanisms, including: 1) inhibiting leukocyte recruitment and aortic wall inflammation, 2) altering MMP expression or activity, or 3) effecting levels of ECM proteins elastin and collagen, ultimately leading to gender-based differences in AAA formation. Clearly, leukocyte recruitment plays a critical role during early AAA formation and data suggest that this is influenced by gonadal hormones. Improved understanding of leukocyte trafficking during AAA formation will help to better elucidate the pathophysiologic mechanism of aneurysm formation in men and women, and may ultimately be expected to translate into novel therapies by which we might treat the large number of patients with small AAAs.

\section{Acknowledgments}

Supported by: NIH KO8 (HL67885-02) (GRU), VonLeibig Award-Lifeline Foundation (GRU), NIH 5R01(HL081629-02) (GRU)

\section{References}

1. Hirsch AT, Haskal ZJ, Hertzer NR, Bakal CW, Creager MA, Halperin JL, Hiratzka LF, Murphy WR, Olin JW, Puschett JB, Rosenfield KA, Sacks D, Stanley JC, Taylor LM Jr, White CJ, White J, White RA, Antman EM, Smith SC Jr, Adams CD, Anderson JL, Faxon DP, Fuster V, Gibbons RJ, Hunt SA, Jacobs AK, Nishimura R, Ornato JP, Page RL, Riegel B. ACC/AHA 2005 Practice Guidelines for the management of patients with peripheral arterial disease (lower extremity, renal, mesenteric, and abdominal aortic): a collaborative report from the American Association for Vascular Surgery/Society for Vascular Surgery, Society for Cardiovascular Angiography and Interventions, Society for Vascular Medicine and Biology, Society of Interventional Radiology, and the ACC/AHA Task Force on Practice Guidelines (Writing Committee to Develop Guidelines for the Management of Patients With Peripheral Arterial Disease): endorsed by the American Association of Cardiovascular and Pulmonary Rehabilitation; National Heart, Lung, and Blood Institute; Society for Vascular Nursing; TransAtlantic Inter-Society Consensus; and Vascular Disease Foundation. Circulation 2006;113(11):e463-654. [PubMed: 16549646] 
2. National Center for Health Statistics (NCHS) NVSS, WISQARS. Query: 20 Leading Causes of Death, United States, 2000-2005, All Races, Both Sexes, Age 55-85. [Accessed March 5, 2008]. Available at: http://www.cdc.gov/ncipc/wisqars/

3. Brewster DC, Cronenwett JL, Hallett JW Jr, Johnston KW, Krupski WC, Matsumura JS. Guidelines for the treatment of abdominal aortic aneurysms. Report of a subcommittee of the Joint Council of the American Association for Vascular Surgery and Society for Vascular Surgery. J Vasc Surg 2003;37(5):1106-1117. [PubMed: 12756363]

4. Cowan JA Jr, Dimick JB, Henke PK, Rectenwald J, Stanley JC, Upchurch GR Jr. Epidemiology of aortic aneurysm repair in the United States from 1993 to 2003. Ann N Y Acad Sci 2006;1085:1-10. [PubMed: 17182917]

5. Lederle FA, Johnson GR, Wilson SE, Chute EP, Hye RJ, Makaroun MS, Barone GW, Bandyk D, Moneta GL, Makhoul RG. The aneurysm detection and management study screening program: validation cohort and final results. Aneurysm Detection and Management Veterans Affairs Cooperative Study Investigators. Arch Intern Med 2000;160(10):1425-1430. [PubMed: 10826454]

6. Lederle FA, Wilson SE, Johnson GR, Reinke DB, Littooy FN, Acher CW, Ballard DJ, Messina LM, Gordon IL, Chute EP, Krupski WC, Busuttil SJ, Barone GW, Sparks S, Graham LM, Rapp JH, Makaroun MS, Moneta GL, Cambria RA, Makhoul RG, Eton D, Ansel HJ, Freischlag JA, Bandyk D. Immediate repair compared with surveillance of small abdominal aortic aneurysms. N Engl J Med 2002;346(19):1437-1444. [PubMed: 12000813]

7. Mastracci TM, Cina CS. Screening for abdominal aortic aneurysm in Canada: review and position statement of the Canadian Society for Vascular Surgery. J Vasc Surg 2007;45(6):1268-1276. [PubMed: 17543696]

8. Schermerhorn ML, O’Malley AJ, Jhaveri A, Cotterill P, Pomposelli F, Landon BE. Endovascular vs. open repair of abdominal aortic aneurysms in the Medicare population. N Engl J Med 2008;358(5):464-474. [PubMed: 18234751]

9. Anidjar S, Dobrin PB, Chejfec G, Michel JB. Experimental study of determinants of aneurysmal expansion of the abdominal aorta. Ann Vasc Surg 1994;8(2):127-136. [PubMed: 8198945]

10. Anidjar S, Dobrin PB, Eichorst M, Graham GP, Chejfec G. Correlation of inflammatory infiltrate with the enlargement of experimental aortic aneurysms. J Vasc Surg 1992;16(2):139-147. [PubMed: 1386635]

11. Anidjar S, Kieffer E. Pathogenesis of acquired aneurysms of the abdominal aorta. Ann Vasc Surg 1992;6(3):298-305. [PubMed: 1610664]

12. Campa JS, Greenhalgh RM, Powell JT. Elastin degradation in abdominal aortic aneurysms. Atherosclerosis 1987;65(1-2):13-21. [PubMed: 3649236]

13. Wassef M, Upchurch GR Jr, Kuivaniemi H, Thompson RW, Tilson MD 3rd. Challenges and opportunities in abdominal aortic aneurysm research. J Vasc Surg 2007;45(1):192-198. [PubMed: 17210410]

14. Alcorn HG, Wolfson SK Jr, Sutton-Tyrrell K, Kuller LH, O’Leary D. Risk factors for abdominal aortic aneurysms in older adults enrolled in The Cardiovascular Health Study. Arterioscler Thromb Vasc Biol 1996;16(8):963-970. [PubMed: 8696960]

15. Lederle FA, Johnson GR, Wilson SE. Abdominal aortic aneurysm in women. J Vasc Surg 2001;34(1):122-126. [PubMed: 11436084]

16. Katz DJ, Stanley JC, Zelenock GB. Gender differences in abdominal aortic aneurysm prevalence, treatment, and outcome. J Vasc Surg 1997;25(3):561-568. [PubMed: 9081139]

17. Bengtsson H, Sonesson B, Bergqvist D. Incidence and prevalence of abdominal aortic aneurysms, estimated by necropsy studies and population screening by ultrasound. Ann N Y Acad Sci 1996;800:1-24. [PubMed: 8958978]

18. Ailawadi G, Eliason JL, Roelofs KJ, Sinha I, Hannawa KK, Kaldjian EP, Lu G, Henke PK, Stanley JC, Weiss SJ, Thompson RW, Upchurch GR Jr. Gender differences in experimental aortic aneurysm formation. Arterioscler Thromb Vasc Biol 2004;24(11):2116-2122. [PubMed: 15331435]

19. Screening for abdominal aortic aneurysm: recommendation statement. Ann Intern Med 2005;142(3):198-202. [PubMed: 15684208] 
20. Kent KC, Zwolak RM, Jaff MR, Hollenbeck ST, Thompson RW, Schermerhorn ML, Sicard GA, Riles TS, Cronenwett JL. Screening for abdominal aortic aneurysm: a consensus statement. J Vasc Surg 2004;39(1):267-269. [PubMed: 14718853]

21. Derubertis BG, Trocciola SM, Ryer EJ, Pieracci FM, McKinsey JF, Faries PL, Kent KC. Abdominal aortic aneurysm in women: prevalence, risk factors, and implications for screening. $\mathrm{J}$ Vasc Surg 2007;46(4):630-635. [PubMed: 17903646]

22. Dillavou ED, Muluk SC, Makaroun MS. A decade of change in abdominal aortic aneurysm repair in the United States: Have we improved outcomes equally between men and women? J Vasc Surg 2006;43(2):230-238. discussion 238. [PubMed: 16476592]

23. Dimick JB, Stanley JC, Axelrod DA, Kazmers A, Henke PK, Jacobs LA, Wakefield TW, Greenfield LJ, Upchurch GR Jr. Variation in death rate after abdominal aortic aneurysmectomy in the United States: impact of hospital volume, gender, and age. Ann Surg 2002;235(4):579-585. [PubMed: 11923615]

24. Heller JA, Weinberg A, Arons R, Krishnasastry KV, Lyon RT, Deitch JS, Schulick AH, Bush HL $\mathrm{Jr}$, Kent KC. Two decades of abdominal aortic aneurysm repair: have we made any progress? J Vasc Surg 2000;32(6):1091-1100. [PubMed: 11107080]

25. Brown LC, Powell JT. Risk factors for aneurysm rupture in patients kept under ultrasound surveillance. UK Small Aneurysm Trial Participants. Ann Surg 1999;230(3):289-296. discussion 296-287. [PubMed: 10493476]

26. Sanchez LA, Rubin BG, Keller CA, Choi ET, Geraghty PJ, Vedantham S, Hovsepian D, Picus D, Sicard GA. Endovascular repair of abdominal aortic aneurysms in women after FDA approval: results, complications, and limitations. Ann Vasc Surg 2002;16(4):430-435. [PubMed: 12134216]

27. Sonesson B, Hansen F, Stale H, Lanne T. Compliance and diameter in the human abdominal aorta--the influence of age and sex. Eur J Vasc Surg 1993;7(6):690-697. [PubMed: 8270073]

28. Sonesson B, Lanne T, Hansen F, Sandgren T. Infrarenal aortic diameter in the healthy person. Eur J Vasc Surg 1994;8(1):89-95. [PubMed: 8307223]

29. Forbes TL, Lawlor DK, DeRose G, Harris KA. Gender differences in relative dilatation of abdominal aortic aneurysms. Ann Vasc Surg 2006;20(5):564-568. [PubMed: 16741651]

30. Solberg S, Singh K, Wilsgaard T, Jacobsen BK. Increased growth rate of abdominal aortic aneurysms in women. The Tromso study. Eur J Vasc Endovasc Surg 2005;29(2):145-149. [PubMed: 15649720]

31. Smith LA, Bukanov NO, Husson H, Russo RJ, Barry TC, Taylor AL, Beier DR, IbraghimovBeskrovnaya O. Development of polycystic kidney disease in juvenile cystic kidney mice: insights into pathogenesis, ciliary abnormalities, and common features with human disease. J Am Soc Nephrol 2006;17(10):2821-2831. [PubMed: 16928806]

32. Nakamura T, Ushiyama C, Suzuki S, Ebihara I, Shimada N, Koide H. Elevation of serum levels of metalloproteinase-1, tissue inhibitor of metalloproteinase-1 and type IV collagen, and plasma levels of metalloproteinase-9 in polycystic kidney disease. Am J Nephrol 2000;20(1):32-36. [PubMed: 10644865]

33. Rosenfeld RG. Hypertension, aortic dilatation and aortic dissection in Turner syndrome: a potentially lethal triad. Clin Endocrinol (Oxf) 2001;54(2):155-156. [PubMed: 11207627]

34. Wizemann, TM.; Pardue, ML., editors. Exploring the biological contributions to human health: does sex matter?. Washington D.C: National Academy Press; 2001.

35. Ailawadi G, Eliason JL, Upchurch GR Jr. Current concepts in the pathogenesis of abdominal aortic aneurysm. J Vasc Surg 2003;38(3):584-588. [PubMed: 12947280]

36. Sinha I, Sinha-Hikim AP, Hannawa KK, Henke PK, Eagleton MJ, Stanley JC, Upchurch GR Jr. Mitochondrial-dependent apoptosis in experimental rodent abdominal aortic aneurysms. Surgery 2005;138(4):806-811. [PubMed: 16269312]

37. Lee JK, Borhani M, Ennis TL, Upchurch GR Jr, Thompson RW. Experimental abdominal aortic aneurysms in mice lacking expression of inducible nitric oxide synthase. Arterioscler Thromb Vasc Biol 2001;21(9):1393-1401. [PubMed: 11557662]

38. Manning MW, Cassi LA, Huang J, Szilvassy SJ, Daugherty A. Abdominal aortic aneurysms: fresh insights from a novel animal model of the disease. Vasc Med 2002;7(1):45-54. [PubMed: 12083734] 
39. Daugherty A, Manning MW, Cassis LA. Angiotensin II promotes atherosclerotic lesions and aneurysms in apolipoprotein E-deficient mice. J Clin Invest 2000;105(11):1605-1612. [PubMed: 10841519]

40. Van Vickle-Chavez SJ, Tung WS, Absi TS, Ennis TL, Mao D, Cobb JP, Thompson RW. Temporal changes in mouse aortic wall gene expression during the development of elastase-induced abdominal aortic aneurysms. J Vasc Surg 2006;43(5):1010-1020. [PubMed: 16678698]

41. Sinha I, Cho BS, Roelofs KJ, Stanley JC, Henke PK, Upchurch GR Jr. Female gender attenuates cytokine and chemokine expression and leukocyte recruitment in experimental rodent abdominal aortic aneurysms. Ann N Y Acad Sci 2006;1085:367-379. [PubMed: 17182958]

42. Curci JA, Liao S, Huffman MD, Shapiro SD, Thompson RW. Expression and localization of macrophage elastase (matrix metalloproteinase-12) in abdominal aortic aneurysms. J Clin Invest 1998;102(11):1900-1910. [PubMed: 9835614]

43. Freestone T, Turner RJ, Coady A, Higman DJ, Greenhalgh RM, Powell JT. Inflammation and matrix metalloproteinases in the enlarging abdominal aortic aneurysm. Arterioscler Thromb Vasc Biol 1995;15(8):1145-1151. [PubMed: 7627708]

44. Longo GM, Xiong W, Greiner TC, Zhao Y, Fiotti N, Baxter BT. Matrix metalloproteinases 2 and 9 work in concert to produce aortic aneurysms. J Clin Invest 2002;110(5):625-632. [PubMed: 12208863]

45. Thompson RW, Holmes DR, Mertens RA, Liao S, Botney MD, Mecham RP, Welgus HG, Parks WC. Production and localization of 92-kilodalton gelatinase in abdominal aortic aneurysms. An elastolytic metalloproteinase expressed by aneurysm-infiltrating macrophages. J Clin Invest 1995;96(1):318-326. [PubMed: 7615801]

46. Pyo R, Lee JK, Shipley JM, Curci JA, Mao D, Ziporin SJ, Ennis TL, Shapiro SD, Senior RM, Thompson RW. Targeted gene disruption of matrix metalloproteinase-9 (gelatinase B) suppresses development of experimental abdominal aortic aneurysms. J Clin Invest 2000;105(11):1641-1649. [PubMed: 10841523]

47. Cohen JR, Keegan L, Sarfati I, Danna D, Ilardi C, Wise L. Neutrophil chemotaxis and neutrophil elastase in the aortic wall in patients with abdominal aortic aneurysms. J Invest Surg 1991;4(4): 423-430. [PubMed: 1777436]

48. Cohen JR, Parikh S, Grella L, Sarfati I, Corbie G, Danna D, Wise L. Role of the neutrophil in abdominal aortic aneurysm development. Cardiovasc Surg 1993;1(4):373-376. [PubMed: 8076062]

49. Fontaine V, Jacob MP, Houard X, Rossignol P, Plissonnier D, Angles-Cano E, Michel JB. Involvement of the mural thrombus as a site of protease release and activation in human aortic aneurysms. Am J Pathol 2002;161(5):1701-1710. [PubMed: 12414517]

50. Eliason JL, Hannawa KK, Ailawadi G, Sinha I, Ford JW, Deogracias M, Roelofs KJ, Woodrum DT, Ennis TL, Henke PK, Stanley JC, Thompson RW, Upchurch GR Jr. Neutrophil Depletion Mediated Experimental Aortic Aneurysm Suppression is Independent of MMP-2 or MMP-9. Circulation. 2005 in press.

51. Ricci MA, Strindberg G, Slaiby JM, Guibord R, Bergersen LJ, Nichols P, Hendley ED, Pilcher DB. Anti-CD 18 monoclonal antibody slows experimental aortic aneurysm expansion. J Vasc Surg 1996;23(2):301-307. [PubMed: 8637107]

52. Charo IF, Taubman MB. Chemokines in the pathogenesis of vascular disease. Circ Res 2004;95(9): 858-866. [PubMed: 15514167]

53. Weber C, Schober A, Zernecke A. Chemokines: key regulators of mononuclear cell recruitment in atherosclerotic vascular disease. Arterioscler Thromb Vasc Biol 2004;24(11):1997-2008. [PubMed: 15319268]

54. Zhao L, Moos MP, Grabner R, Pedrono F, Fan J, Kaiser B, John N, Schmidt S, Spanbroek R, Lotzer K, Huang L, Cui J, Rader DJ, Evans JF, Habenicht AJ, Funk CD. The 5-lipoxygenase pathway promotes pathogenesis of hyperlipidemia-dependent aortic aneurysm. Nat Med 2004;10(9):966-973. [PubMed: 15322539]

55. Koch AE, Kunkel SL, Harlow LA, Johnson B, Evanoff HL, Haines GK, Burdick MD, Pope RM, Strieter RM. Enhanced production of monocyte chemoattractant protein-1 in rheumatoid arthritis. J Clin Invest 1992;90(3):772-779. [PubMed: 1522232] 
56. Lu B, Rutledge BJ, Gu L, Fiorillo J, Lukacs NW, Kunkel SL, North R, Gerard C, Rollins BJ. Abnormalities in monocyte recruitment and cytokine expression in monocyte chemoattractant protein 1-deficient mice. J Exp Med 1998;187(4):601-608. [PubMed: 9463410]

57. Yla-Herttuala S, Lipton BA, Rosenfeld ME, Sarkioja T, Yoshimura T, Leonard EJ, Witztum JL, Steinberg D. Expression of monocyte chemoattractant protein 1 in macrophage-rich areas of human and rabbit atherosclerotic lesions. Proc Natl Acad Sci U S A 1991;88(12):5252-5256. [PubMed: 2052604]

58. Colonnello JS, Hance KA, Shames ML, Wyble CW, Ziporin SJ, Leidenfrost JE, Ennis TL, Upchurch GR Jr, Thompson RW. Transient exposure to elastase induces mouse aortic wall smooth muscle cell production of MCP-1 and RANTES during development of experimental aortic aneurysm. J Vasc Surg 2003;38(1):138-146. [PubMed: 12844103]

59. Koch AE, Kunkel SL, Pearce WH, Shah MR, Parikh D, Evanoff HL, Haines GK, Burdick MD, Strieter RM. Enhanced production of the chemotactic cytokines interleukin-8 and monocyte chemoattractant protein-1 in human abdominal aortic aneurysms. Am J Pathol 1993;142(5):14231431. [PubMed: 8494046]

60. Ishibashi M, Egashira K, Zhao Q, Hiasa K, Ohtani K, Ihara Y, Charo IF, Kura S, Tsuzuki T, Takeshita A, Sunagawa K. Bone marrow-derived monocyte chemoattractant protein-1 receptor CCR2 is critical in angiotensin II-induced acceleration of atherosclerosis and aneurysm formation in hypercholesterolemic mice. Arterioscler Thromb Vasc Biol 2004;24(11):e174-178. [PubMed: 15331433]

61. Juvonen J, Surcel HM, Satta J, Teppo AM, Bloigu A, Syrjala H, Airaksinen J, Leinonen M, Saikku $\mathrm{P}$, Juvonen T. Elevated circulating levels of inflammatory cytokines in patients with abdominal aortic aneurysm. Arterioscler Thromb Vasc Biol 1997;17(11):2843-2847. [PubMed: 9409264]

62. Pearce WH, Sweis I, Yao JS, McCarthy WJ, Koch AE. Interleukin-1 beta and tumor necrosis factor-alpha release in normal and diseased human infrarenal aortas. J Vasc Surg 1992;16(5):784789. [PubMed: 1433667]

63. Dinarello CA. Biologic basis for interleukin-1 in disease. Blood 1996;87(6):2095-2147. [PubMed: 8630372]

64. Reginato AM, Sanz-Rodriguez C, Diaz A, Dharmavaram RM, Jimenez SA. Transcriptional modulation of cartilage-specific collagen gene expression by interferon gamma and tumour necrosis factor alpha in cultured human chondrocytes. Biochem J 1993;294 (Pt 3):761-769. [PubMed: 8379931]

65. Hamano K, Li TS, Takahashi M, Kobayashi T, Shirasawa B, Ito H, Zempo N. Enhanced tumor necrosis factor- alpha expression in small sized abdominal aortic aneurysms. World J Surg 2003;27(4):476-480. [PubMed: 12658496]

66. Ley, K. The selectins as rolling receptors. In: Vestweber, D., editor. The Selectins. Vol. 3. Amsterdam; Harwood: 1997. p. 63-104.

67. Vestweber D, Blanks JE. Mechanisms that regulate the function of the selectins and their ligands. Physiol Rev 1999;79(1):181-213. [PubMed: 9922371]

68. Arbones ML, Ord DC, Ley K, Ratech H, Maynard-Curry C, Otten G, Capon DJ, Tedder TF. Lymphocyte homing and leukocyte rolling and migration are impaired in L-selectin-deficient mice. Immunity 1994;1(4):247-260. [PubMed: 7534203]

69. Bullard DC, Kunkel EJ, Kubo H, Hicks MJ, Lorenzo I, Doyle NA, Doerschuk CM, Ley K, Beaudet AL. Infectious susceptibility and severe deficiency of leukocyte rolling and recruitment in E-selectin and P-selectin double mutant mice. J Exp Med 1996;183(5):2329-2336. [PubMed: 8642341]

70. Bullard DC, Qin L, Lorenzo I, Quinlin WM, Doyle NA, Bosse R, Vestweber D, Doerschuk CM, Beaudet AL. P-selectin/ICAM-1 double mutant mice: acute emigration of neutrophils into the peritoneum is completely absent but is normal into pulmonary alveoli. J Clin Invest 1995;95(4): 1782-1788. [PubMed: 7535798]

71. Johnson RC, Mayadas TN, Frenette PS, Mebius RE, Subramaniam M, Lacasce A, Hynes RO, Wagner DD. Blood cell dynamics in P-selectin-deficient mice. Blood 1995;86(3):1106-1114. [PubMed: 7542495] 
72. Tedder TF, Steeber DA, Pizcueta P. L-selectin-deficient mice have impaired leukocyte recruitment into inflammatory sites. J Exp Med 1995;181(6):2259-2264. [PubMed: 7539045]

73. Hannawa KK, Eliason JL, Woodrum DT, Pearce CG, Roelofs KJ, Grigoryants V, Eagleton MJ, Henke PK, Wakefield TW, Myers DD, Stanley JC, Upchurch GR Jr. L-selectin-mediated neutrophil recruitment in experimental rodent aneurysm formation. Circulation 2005;112(2):241247. [PubMed: 15998669]

74. Hannawa KK, Cho BS, Sinha I, Roelofs KJ, Myers DD, Wakefield TJ, Stanley JC, Henke PK, Upchurch GR Jr. Attenuation of experimental aortic aneurysm formation in P-selectin knockout mice. Ann N Y Acad Sci 2006;1085:353-359. [PubMed: 17182955]

75. Martin-McNulty B, Tham DM, da Cunha V, Ho JJ, Wilson DW, Rutledge JC, Deng GG, Vergona R, Sullivan ME, Wang YX. 17 Beta-estradiol attenuates development of angiotensin II-induced aortic abdominal aneurysm in apolipoprotein E-deficient mice. Arterioscler Thromb Vasc Biol 2003;23(9):1627-1632. [PubMed: 12855485]

76. Henriques TA, Huang J, D’Souza SS, Daugherty A, Cassis LA. Orchidectomy, but not ovariectomy, regulates angiotensin II-induced vascular diseases in apolipoprotein E-deficient mice. Endocrinology 2004;145(8):3866-3872. [PubMed: 15105380]

77. Angele MK, Knoferl MW, Ayala A, Bland KI, Chaudry IH. Testosterone and estrogen differently effect Th1 and Th2 cytokine release following trauma-haemorrhage. Cytokine 2001;16(1):22-30. [PubMed: 11669583]

78. Angele MK, Knoferl MW, Schwacha MG, Ayala A, Cioffi WG, Bland KI, Chaudry IH. Sex steroids regulate pro- and anti-inflammatory cytokine release by macrophages after traumahemorrhage. Am J Physiol 1999;277(1 Pt 1):C35-42. [PubMed: 10409106]

79. Angele MK, Schwacha MG, Ayala A, Chaudry IH. Effect of gender and sex hormones on immune responses following shock. Shock 2000;14(2):81-90. [PubMed: 10947147]

80. Kahlke V, Angele MK, Ayala A, Schwacha MG, Cioffi WG, Bland KI, Chaudry IH. Immune dysfunction following trauma-haemorrhage: influence of gender and age. Cytokine 2000;12(1): 69-77. [PubMed: 10623445]

81. Knoferl MW, Angele MK, Diodato MD, Schwacha MG, Ayala A, Cioffi WG, Bland KI, Chaudry IH. Female sex hormones regulate macrophage function after trauma-hemorrhage and prevent increased death rate from subsequent sepsis. Ann Surg 2002;235(1):105-112. [PubMed: 11753049]

82. Knoferl MW, Jarrar D, Angele MK, Ayala A, Schwacha MG, Bland KI, Chaudry IH. 17 betaEstradiol normalizes immune responses in ovariectomized females after trauma-hemorrhage. Am J Physiol Cell Physiol 2001;281(4):C1131-1138. [PubMed: 11546648]

83. Miller AP, Feng W, Xing D, Weathington NM, Blalock JE, Chen YF, Oparil S. Estrogen modulates inflammatory mediator expression and neutrophil chemotaxis in injured arteries. Circulation 2004;110(12):1664-1669. [PubMed: 15353495]

84. Oparil S, Levine RL, Chen SJ, Durand J, Chen YF. Sexually dimorphic response of the ballooninjured rat carotid artery to hormone treatment. Circulation 1997;95(5):1301-1307. [PubMed: 9054863]

85. Xing D, Miller A, Novak L, Rocha R, Chen YF, Oparil S. Estradiol and progestins differentially modulate leukocyte infiltration after vascular injury. Circulation 2004;109(2):234-241. [PubMed: 14699005]

86. Jilma B, Jilma-Stohlawetz P. Female gender, menstrual cycle and estradiol affect plasma levels of monocyte chemotactic protein-1 (MCP-1) in humans. Cardiovasc Res 2002;55(2):416. author reply 417. [PubMed: 12123781]

87. Rodriguez E, Lopez R, Paez A, Masso F, Montano LF. 17Beta-estradiol inhibits the adhesion of leukocytes in TNF-alpha stimulated human endothelial cells by blocking IL-8 and MCP-1 secretion, but not its transcription. Life Sci 2002;71(18):2181-2193. [PubMed: 12204776]

88. Seli E, Pehlivan T, Selam B, Garcia-Velasco JA, Arici A. Estradiol down-regulates MCP-1 expression in human coronary artery endothelial cells. Fertil Steril 2002;77(3):542-547. [PubMed: 11872210] 
89. Yamada K, Hayashi T, Kuzuya M, Naito M, Asai K, Iguchi A. Physiological concentration of 17 beta-estradiol inhibits chemotaxis of human monocytes in response to monocyte chemotactic protein 1. Artery 1996;22(1):24-35. [PubMed: 8781708]

90. Sudhir K, Chou TM, Chatterjee K, Smith EP, Williams TC, Kane JP, Malloy MJ, Korach KS, Rubanyi GM. Premature coronary artery disease associated with a disruptive mutation in the estrogen receptor gene in a man. Circulation 1997;96(10):3774-3777. [PubMed: 9396482]

91. Shearman AM, Cupples LA, Demissie S, Peter I, Schmid CH, Karas RH, Mendelsohn ME, Housman DE, Levy D. Association between estrogen receptor alpha gene variation and cardiovascular disease. JAMA 2003;290(17):2263-2270. [PubMed: 14600184]

92. Ogawa S, Emi M, Shiraki M, Hosoi T, Ouchi Y, Inoue S. Association of estrogen receptor beta (ESR2) gene polymorphism with blood pressure. J Hum Genet 2000;45(6):327-330. [PubMed: 11185739]

93. Halpern, VJ.; Song, X.; Faust, GR. Estrogen inhibits elastase secretion from U937 cells via nitric oxide. Lifeline Foundation Research Forum, Society of Vascular Surgery; 2003.

94. Potier M, Karl M, Elliot SJ, Striker GE, Striker LJ. Response to sex hormones differs in atherosclerosis-susceptible and -resistant mice. Am J Physiol Endocrinol Metab 2003;285(6):E1237-1245. [PubMed: 12915398]

95. Sullivan TR Jr, Karas RH, Aronovitz M, Faller GT, Ziar JP, Smith JJ, O’Donnell TF Jr, Mendelsohn ME. Estrogen inhibits the response-to-injury in a mouse carotid artery model. J Clin Invest 1995;96(5):2482-2488. [PubMed: 7593638]

96. Fischer GM, Swain ML. Effect of sex hormones on blood pressure and vascular connective tissue in castrated and noncastrated male rats. Am J Physiol 1977;232(6):H617-621. [PubMed: 879300]

97. Simpson CF, Cardeilhac PT. Mortality, hemodynamics, and aortic properties among male and female turkeys fed beta-aminopropionitrile. Proc Soc Exp Biol Med 1983;172(2):168-172. [PubMed: 6828461]

98. van der Schouw YT, Pijpe A, Lebrun CE, Bots ML, Peeters PH, van Staveren WA, Lamberts SW, Grobbee DE. Higher usual dietary intake of phytoestrogens is associated with lower aortic stiffness in postmenopausal women. Arterioscler Thromb Vasc Biol 2002;22(8):1316-1322. [PubMed: 12171794] 


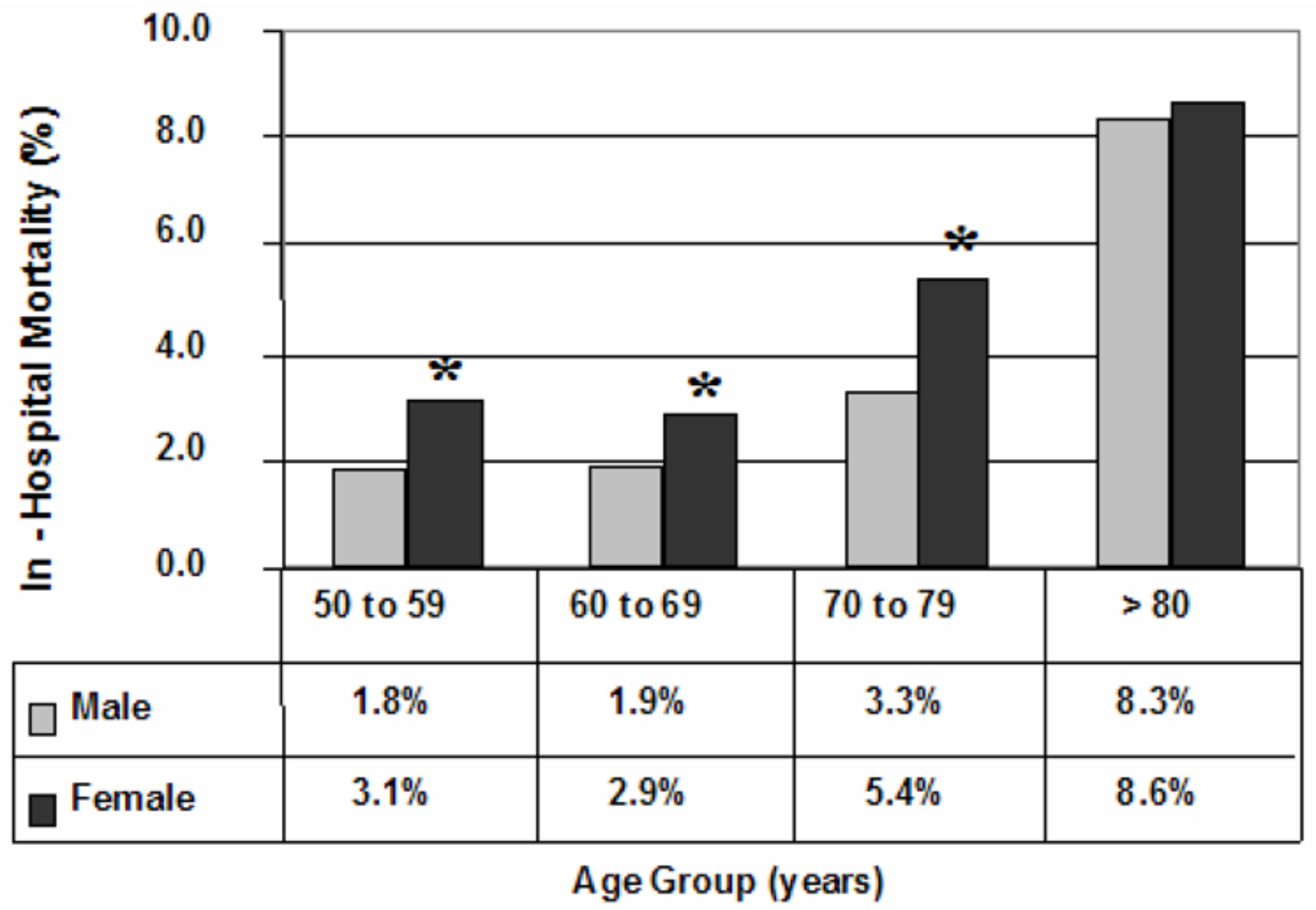

Figure 1.

Comparison of in-hospital mortality rates for elective AAA repair documenting increased mortality in females compared with males. $* \mathrm{P}<.05$. (Reproduced with permission from Dimick JB, Stanley JC, Axelrod DA, et al. Ann Surg. 2002;235(4):579-585.) ${ }^{23}$ 
Mouse elastase aneurysms

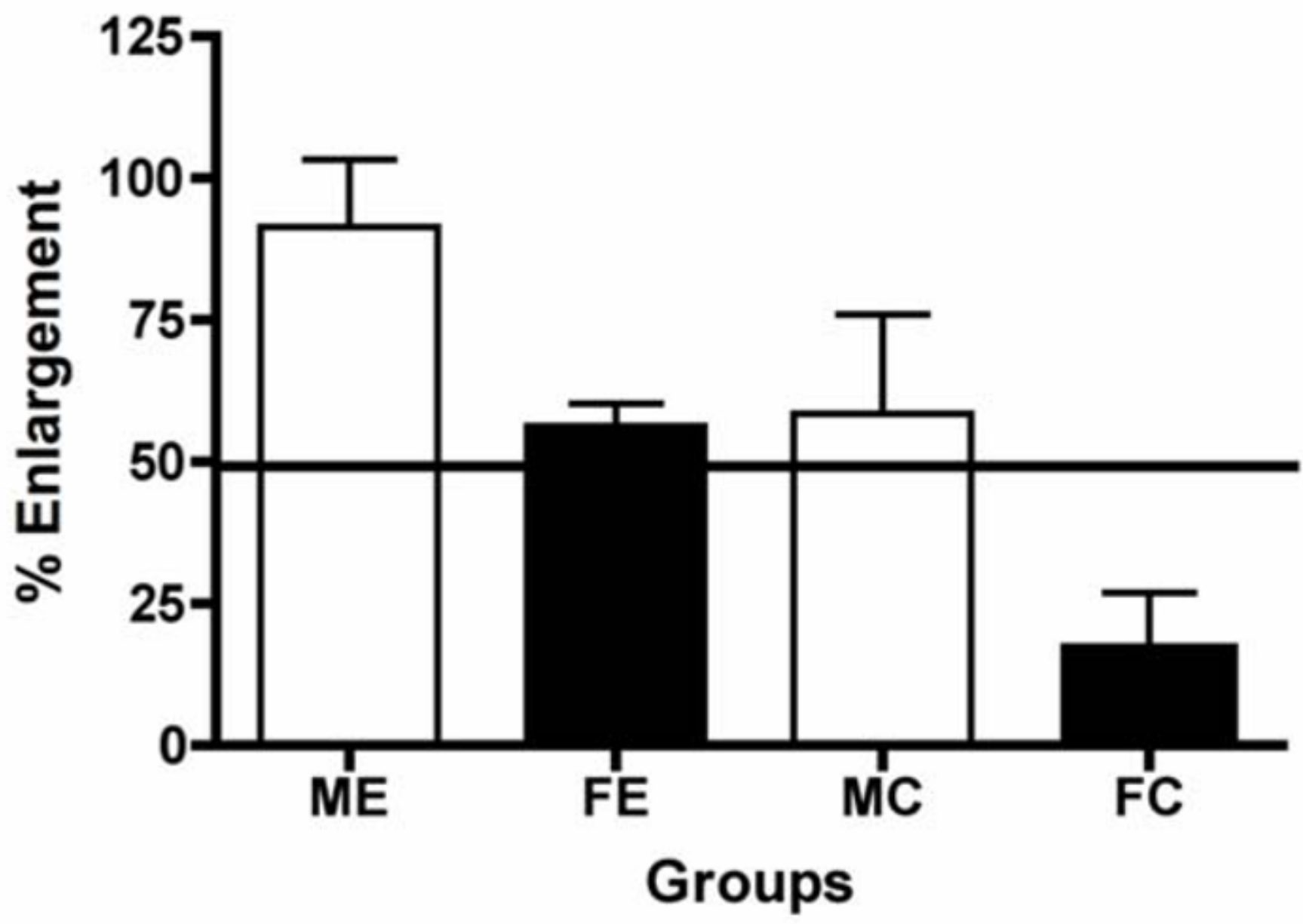

Figure 2.

(A) Bar graph representing greater increase in aortic diameters of male mouse aortas versus female mouse aortas at 14 days post-elastase perfusion. Y- axis indicates \% enlargement of aortic diameter calculated as follows: $\{[$ post $(\mathrm{AD}-$ pre AD)/pre AD]*100 $\}$. Groups: $\mathrm{M}=$ male mice, $\mathrm{F}=$ female mice, $\mathrm{E}=$ elastase perfused aortas, $\mathrm{C}=$ inactivated elastase perfused aortas. (B) Bar graph representing MMP9 and MMP2 activity levels analyzed via zymography in male and female mouse aortas harvested at 14 days post-elastase perfusion. There was a significantly greater amount of MMP 9 activity in male elastase perfused aortas $(\mathrm{ME})$ versus female elastase perfused aortas $(\mathrm{FE})(\mathrm{P}=0.016)$. There was no significant difference in MMP2 activity levels between the two groups. The y-axis represents integrated optical density (IOD) of zymogen activity levels corrected for total protein. 


\section{MMP activity in 14 day elastase perfused mouse aortas}
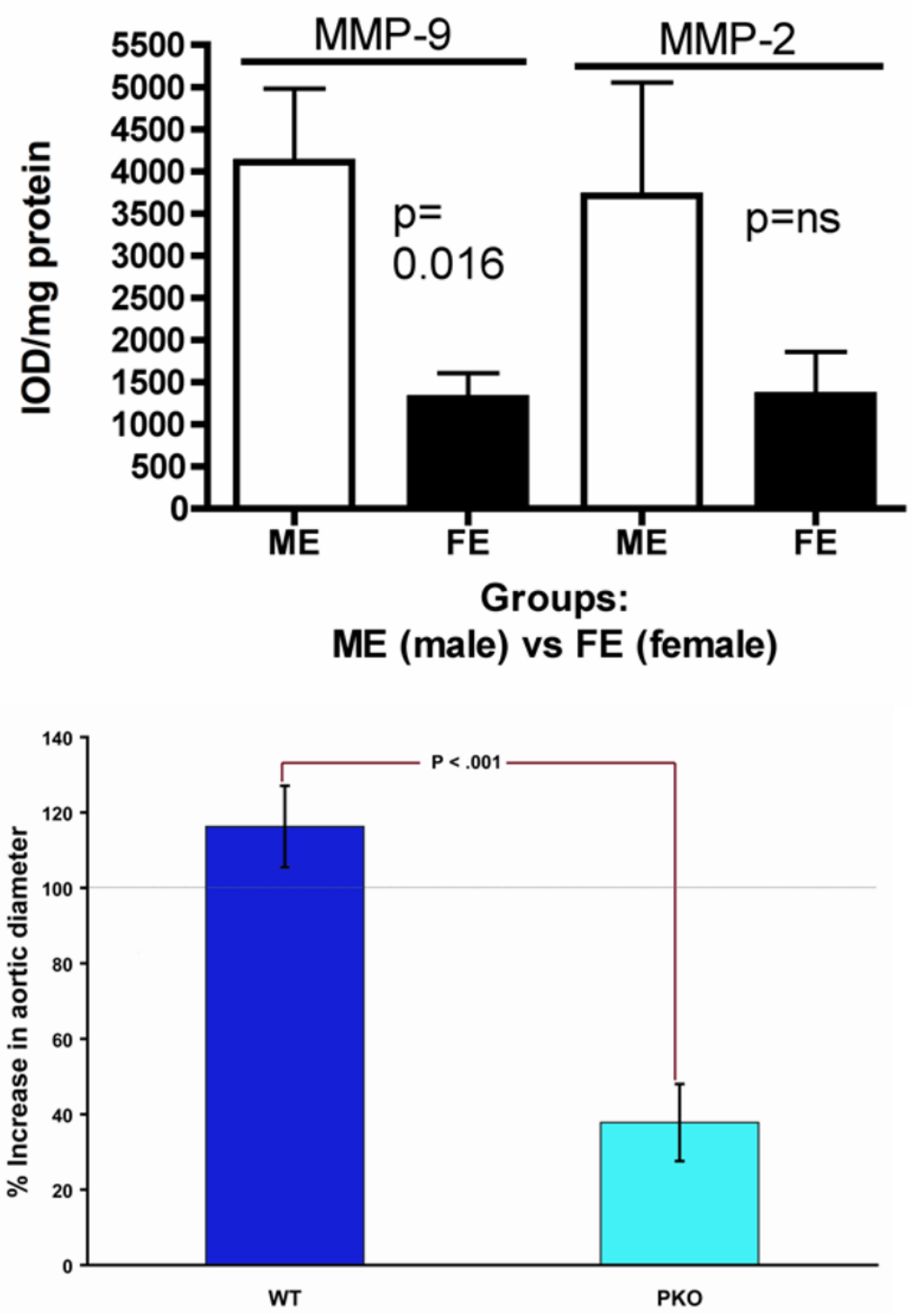

Figure 3.

WT mice had significantly larger aortic diameters compared to PKO mice at day 14 post elastase perfusion ( $116 \%$ vs. $38 \%, \mathrm{P}<0.001)$. In addition, aortic aneurysm incidence was $52 \%$ in WT mice and $0 \%(\mathrm{P}=0.01)$ in PKO mice. An aortic aneurysm was defined as a $100 \%$ or greater increase in $\mathrm{AD}$ from pre-perfusion measurement. (Reproduced with permission from Hannawa KK, Cho BS, Sinha I, et al. Ann N Y Acad Sci. 2006;1085:353359. $)^{74}$ 


\section{Table 1}

\section{Differences in Hospital Death Rates between Genders}

Unadjusted In-Hospital Mortality Rates for Patients Undergoing Repair of Intact and Ruptured Abdominal Aortic Aneurysm in the United States, 1996 to 1997.

\begin{tabular}{|c|c|c|c|}
\hline & $\underset{(\%)}{\text { OVERALL MORTALITY RATE }}$ & $\begin{array}{l}\text { MORTALITY AT HIGH VOLUME } \\
\text { HOSPITALS }(\%)\end{array}$ & $\begin{array}{l}\text { MORTALITY AT LOW VOLUME } \\
\text { HOSPITALS }(\%)\end{array}$ \\
\hline \multicolumn{4}{|c|}{ INTACT ABDOMINAL AORTIC ANEURYSM REPAIR } \\
\hline \multicolumn{4}{|c|}{ AGE $<65$ YEARS } \\
\hline $\mathrm{Male}^{\dagger}$ & $1.6 \%$ & $0.8 \%$ & $2.5 \%$ \\
\hline Female $^{\dagger}$ & $2.8 \%$ & $1.9 \%$ & $3.9 \%$ \\
\hline \multicolumn{4}{|c|}{ AGE $>65$ YEARS } \\
\hline $\mathrm{Male}^{\dagger}$ & $3.9 \%$ & $3.2 \%$ & $4.6 \%$ \\
\hline $\mathrm{Female}^{\dagger}$ & $5.6 \%$ & $4.4 \%$ & $7.1 \%$ \\
\hline \multicolumn{4}{|c|}{ RUPTURED ABDOMINAL AORTIC ANEURYSM REPAIR } \\
\hline \multicolumn{4}{|c|}{ AGE $<65$ YEARS } \\
\hline Male & $29.8 \%$ & $30.6 \%$ & $29.1 \%$ \\
\hline Female $^{\dagger}$ & $56.7 \%$ & $50.0 \%$ & $61.1 \%$ \\
\hline \multicolumn{4}{|c|}{ AGE > 65 YEARS } \\
\hline $\mathrm{Male}^{\dagger}$ & $47.0 \%$ & $41.5 \%$ & $50.8 \%$ \\
\hline Female $^{\dagger}$ & $57.1 \%$ & $55.2 \%$ & $58.2 \%$ \\
\hline
\end{tabular}

Modified from Dimick JB, Stanley JC, Axelrod DA, et al. Ann Surg. 2002;235(4):579-585. ${ }^{23}$ 
Table 2

Superarray data from male and female elastase perfused AAAs documenting down regulation of a number of gene families in females compared with males.

\begin{tabular}{|c|c|}
\hline Cytokine/Chemokine & Fold Decrease in Females \\
\hline \multicolumn{2}{|c|}{ Bone Morphogenetic Protein (BMP) Family } \\
\hline BMP-1 & 6.1 \\
\hline BMP-6 & 6.3 \\
\hline BMP-7 & 5.6 \\
\hline BMP-15 & 6.3 \\
\hline \multicolumn{2}{|c|}{ C-C Chemokine Ligand Family } \\
\hline CCL 24 & ND \\
\hline CCL 25 & ND \\
\hline CCL 28 & ND \\
\hline \multicolumn{2}{|c|}{ C-C Chemokine Receptor Family } \\
\hline CCR 2 & ND \\
\hline CCR-7 & ND \\
\hline CCR-8 & ND \\
\hline \multicolumn{2}{|l|}{ Interleukin (IL) Family } \\
\hline IL-1 & 6.2 \\
\hline IL-2 & 6.1 \\
\hline IL-3 & 4.9 \\
\hline IL-5 & 4.9 \\
\hline IL-7 & 5.9 \\
\hline IL-11 & 6 \\
\hline IL-12 & 6.3 \\
\hline \multicolumn{2}{|c|}{ Transforming Growth Factor (TGF) Family } \\
\hline TGF- $\beta 1$ & 4.1 \\
\hline TGF- $\beta 2$ & 4.2 \\
\hline \multicolumn{2}{|c|}{ Tumor Necrosis Factor (TNF) Family } \\
\hline TNFSF-4 & ND \\
\hline TNFSF-6 & ND \\
\hline TNFSF-9 & ND \\
\hline TNFSF-15 & ND \\
\hline \multicolumn{2}{|c|}{ Vascular Endothelial Growth Factor Family } \\
\hline VEGF-1 & 3.6 \\
\hline VEGF-2 & 3.6 \\
\hline
\end{tabular}

ND- denotes expression was present in males, but not detectable in females

Modified from Sinha I, Cho BS, Roelofs KJ, et al. Ann N Y Acad Sci. 2006;1085:367-379.41 